\title{
Expression of Bovine Parathyroid Hormone/Parathyroid Hormone- Related Protein (PTH/PTHrP) Receptor mRNA in the Mammary Gland of Cows
}

\author{
Ken $\mathrm{ONDA}^{1)}$, Naoaki MATSUKI ${ }^{2)}$, Kenichiro $\mathrm{ONO}^{2)}$ and Yasunori WADA ${ }^{1) *}$ \\ ${ }^{1)}$ Laboratory of Internal Medicine III, Azabu University School of Veterinary Medicine, 1-17-71 Fuchinobe, Kanagawa 229-8501 and \\ ${ }^{2)}$ Department of Veterinary Clinical Pathobiology, Graduate School of Agricultural and Life Sciences, The University of Tokyo, 1-1-1 \\ Yayoi, Bunkyo-ku, Tokyo 113-8657, Japan
}

(Received 12 August 2005/Accepted 31 January 2006)

ABSTRACT. To examine the PTH/PTHrP receptor in the mammary gland, molecular cloning of bovine PTH/PTHrP receptor and measurement of its mRNA expression were carried out in cows during the periparturient period. The $\mathrm{PTH} / \mathrm{PTHrP}$ receptor gene was partially cloned, and expression of bovine PTH/PTHrP receptor mRNA was detected in various tissues of the cow. In the mammary gland, PTH/ PTHrP receptor mRNA expression was constantly low during the periparturient period, whereas PTHrP mRNA expression dramatically increased after parturition. This suggested that expression of PTH/PTHrP receptor mRNA in the mammary gland is not affected by lactation in cows.

KEY WORDS: bovine, mammary gland, PTH/PTHrP receptor mRNA.

J. Vet. Med. Sci. 68(6): 623-625, 2006

Parathyroid hormone (PTH) / parathyroid hormonerelated protein (PTHrP) receptor shows the same binding affinity and biological activity for PTH as it does for PTHrP $[1,2]$. Tian et al. [7] and Urena et al. [8] demonstrated that $\mathrm{PTH} / \mathrm{PTHrP}$ receptor mRNA is expressed in various tissues, including the kidneys, bones, and mammary glands of rats. Since both PTH and PTHrP regulate calcium resorption and absorption in various tissues, $\mathrm{PTH} / \mathrm{PTHrP}$ receptor is considered the most important modulating factor for calcium homeostasis. Although PTHrP is synthesized and secreted in the mammary gland $[4,5]$ of cows and a large amount of it has been observed in milk with an increase throughout the lactation period [6], there is little information available on the PTH/PTHrP receptor in the mammary gland of cows. This note deals with the expression of $\mathrm{PTH} / \mathrm{PTHrP}$ receptor mRNA in the mammary gland of cows during the periparturient period.

One non-pregnant and non-lactating Holstein cow was slaughtered and used for molecular cloning of PTH/PTHrP receptor gene and mRNA expression in tissues. Tissue samples, included heart, lung, liver, spleen, kidney, uterus, ovary, mammary gland, skeletal muscle, cerebrum, cerebellum, tongue, esophagus, rumen, reticulum, omasum, abomasum, duodenum, ileum, cecum, colon, and rectum, were collected and immediately stored in liquid nitrogen until use. The kidney was used from among the samples for molecular cloning of PTH/PTHrP receptor gene. Another 2 cows, a Jersey cow aged 5 years old that had calved twice and a Holstein cow aged 3 years old that had never calved, were used for expression of PTH/PTHrP receptor mRNA in the mammary gland during the periparturient period. Tissue samples were collected 2 and 3 weeks before the day of

\footnotetext{
* Correspondence to: WadA, Y., Laboratory of Internal Medicine III, Azabu University School of Veterinary Medicine, 1-17-71 Fuchinobe, Kanagawa 229-8501, Japan.
}

calving, and every 2 weeks at the same time (2:00 P.M.) for the next 8 or 9 weeks, according to our previous report [3]. The samples were stored in liquid nitrogen until use. After sample collection, both cows were in good health and milked twice daily. A Holstein cow, non-lactating and nonpregnant, was also used as a negative control for surgical invasion of the mammary gland. This experiment was approved by the Animal Care and Use Committee of the Azabu University School of Veterinary Medicine (No.67 and 75).

For molecular cloning of bovine $\mathrm{PTH} / \mathrm{PTHrP}$ receptor cDNA, total RNA from frozen kidney tissue was isolated according to our previous report [3]. The cDNA obtained from the kidney tissue was amplified by polymerase chain reaction (PCR) using primer pair p1 and p2 (Table 1). Both primers were synthesized on the cDNA sequences of human PTH/PTHrP receptor (accession number U17418). The DNA fragment amplified with primers $\mathrm{p} 1$ and $\mathrm{p} 2$ was cloned into pCRII vector using a TA cloning kit (Invitrogen, CA, U.S.A.) and sequenced using an automatic DNA sequencer. Based on the sequence of the PCR amplified cDNA fragment, nested primers $\mathrm{p} 3$ and $\mathrm{p} 4$ were synthesized. A SMART RACE cDNA Amplification kit (Clontech, CA, U.S.A.) and $1.2 \mu \mathrm{g}$ of mRNA were used for 5 ' and 3' RACE. Reactions were performed with combinations of primers $\mathrm{p} 3$ and $\mathrm{p} 4$, and adaptor primers complementary to the sequences of the adaptors added at the 5' and 3' ends. The resultant overlapping 5' or 3' RACE products were cloned into pCRII vector and sequenced on both strands. In this experiment, the cDNA sequences were 1078 nucleotides in length with a 903 base pair open reading frame that encoded 300 amino acid residues (accession number AB239131). A polyadenylation sequence was included, although the 5' cDNA end was not completely identified. This deduced amino acid sequence was $94.0 \%$ and $87.3 \%$ identical to that of human $\mathrm{PTH} / \mathrm{PTHrP}$ receptor and mouse 
Table 1. Sequences of primers used for PCR

\begin{tabular}{|c|c|c|c|c|c|}
\hline Transcript & Primer & Location (nt) & Sequence (5' to $\left.3^{\prime}\right)$ & Product (bp) & Accession \\
\hline \multirow[t]{4}{*}{ PTH/PTHrP receptor } & $\mathrm{p} 15$, & $1336-1362$ & TCAАСТTCATCСТСТTCATCAATATCG & \multirow[t]{2}{*}{299} & \multirow[t]{4}{*}{ U17418 } \\
\hline & p2 3 ' & $1634-1610$ & TTTCTTGATCTCAGCTTGTACCTCG & & \\
\hline & p3 5, & & AAATCCACACTGGTGCTCATGCCGC & \multirow[t]{2}{*}{165} & \\
\hline & p4 3' & & GCAGAAACAGTATATGATGGC & & \\
\hline \multirow[t]{2}{*}{ PTHrP } & 5 , & $74-95$ & GTGGTGTGGAAAAAACACGGTT & \multirow[t]{2}{*}{483} & \multirow[t]{2}{*}{ AB097837 } \\
\hline & 3 ' & $554-534$ & TCTTTTCCTGCTCCTTGCGTT & & \\
\hline \multirow[t]{2}{*}{ GAPDH } & 5 , & 186-209 & САCСАTCTTCCAGGAGCGAGATCC & \multirow[t]{2}{*}{578} & \multirow[t]{2}{*}{ U85042 } \\
\hline & 3 ' & $761-738$ & GACGCCTGCTTCACCACCTTCTTG & & \\
\hline
\end{tabular}

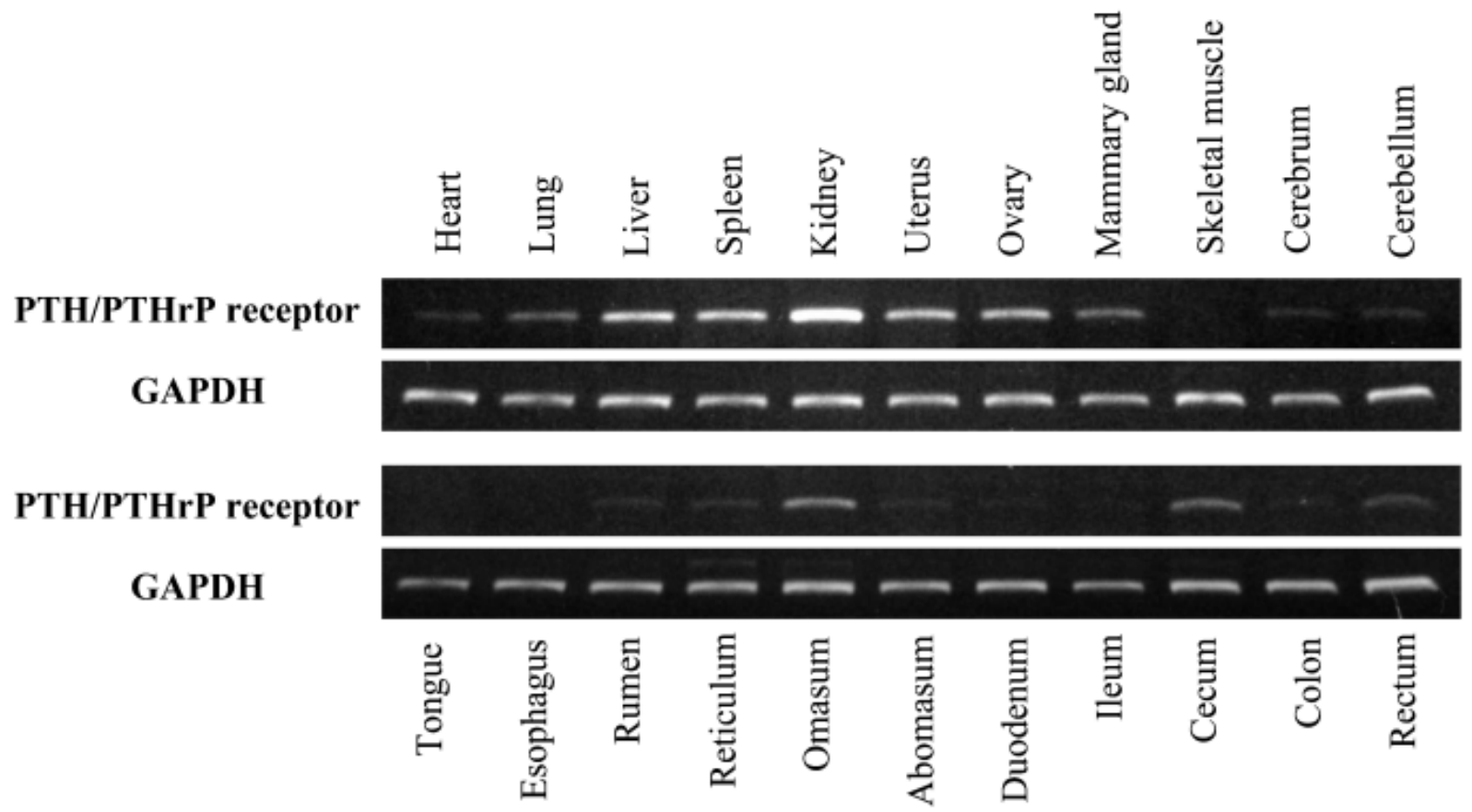

Fig. 1. Expression of PTH/PTHrP receptor mRNA in various tissues of a cow.

PTH/PTHrP receptor, respectively.

For PCR, the primer pairs shown in Table 1 were used to detect the expression of $\mathrm{PTH} / \mathrm{PTHrP}$ receptor ( $\mathrm{p} 3$ and $\mathrm{p} 4)$, PTHrP, and glyceraldehyde-3-phosphate (GAPDH) mRNA. The PCR reaction was carried out in a total volume of $20 \mu l$ containing $10 \mathrm{mM}$ Tris- $\mathrm{HCl}(\mathrm{pH} 8.0), 50 \mathrm{mM} \mathrm{KCl}, 20 \mathrm{mM}$ $\mathrm{MgCl}_{2}, 0.2 \mathrm{mM}$ of each dNTP, $0.5 \mu \mathrm{M}$ of each primer, and $1 \mathrm{U}$ of DNA polymerase mixture (Takara Ex Taq, Takara, Tokyo, Japan) with cDNA. After denaturation at $94^{\circ} \mathrm{C}$ for 1 $\mathrm{min}$, the thermal cycling parameters were as follows: denaturation at $94^{\circ} \mathrm{C}$ for $45 \mathrm{sec}$, annealing at $62^{\circ} \mathrm{C}$ for $45 \mathrm{sec}$, extension for $60 \mathrm{sec}$ at $72^{\circ} \mathrm{C}$ for 30 cycles, and extension at $72^{\circ} \mathrm{C}$ for $5 \mathrm{~min}$. The PCR products were separated on $1.5 \%$ agarose gels in $1 \times \mathrm{TBE}$ and visualized with ethidium bromide. Expression of PTH/PTHrP receptor mRNA was detected in various tissues of the cows, especially in the liver, spleen, kidney, uterus, ovary, mammary gland, oma- sum and cecum (Fig. 1).

In the mammary gland of periparturient cows, expression of PTH/PTHrP receptor mRNA was basically low, and no remarkable increases were observed during lactation; however, expression of PTHrP mRNA significantly increased after parturition (Fig. 2). Urena et al. [8] speculated that the low level of PTH/PTHrP receptor mRNA expression may reflect receptor down regulation due to high levels of PTHrP based on data from prelactating mammary tissue in rats. Wojcik et al. [9] concluded that the patterns observed for PTHrP and the PTH/PTHrP receptor support autcrine and/or paracrine functions for PTHrP in the lactating mammary gland of rats. In this experiment, no remarkable correlation in mRNA expression between PTHrP and PTH/PTHrP receptor was observed throughout the periparturient period, from late pregnancy to full lactation, suggesting that PTH/ PTHrP receptor mRNA expression in the mammary gland 

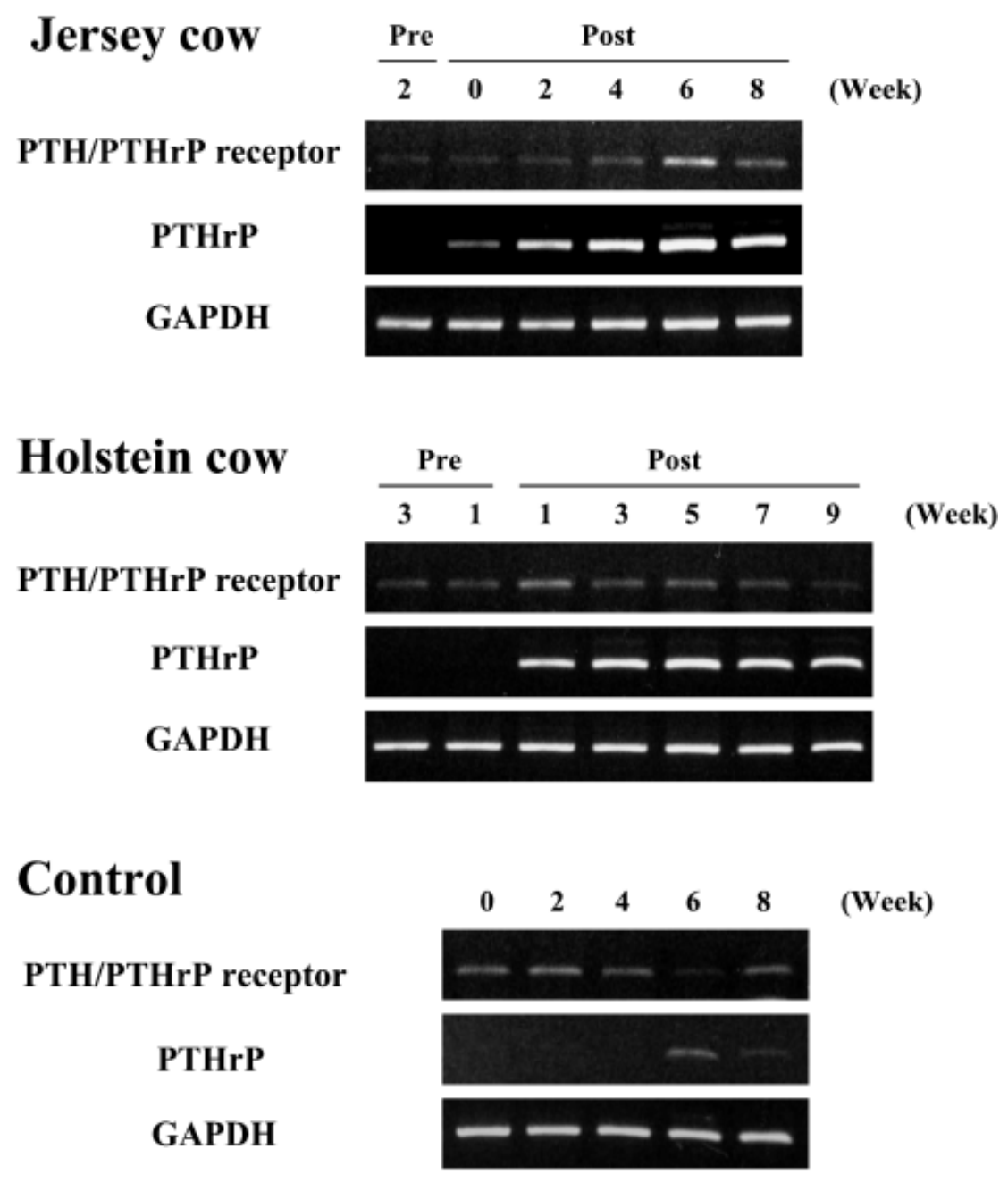

Fig. 2. Expression of PTH/PTHrP receptor mRNA in the periarturient mammary glands of cows.

of cows is not affected by the increase of PTHrP at the onset of lactation.

ACKNOWLEDGEMENT. This work was supported in part by a Grant-in Aid from the MORINAGA HOSHI-KAI, Japan.

\section{REFERENCES}

1. Gardella, T. J. and Juppner, H. 2001. Trends Endocrinol. Metab. 12: 210-217.

2. Mannstadt, M., Juppner, H. and Gardella, T. J. 1999. Am. J. Physiol. 277: F665-675.

3. Onda, K., Matsuki, N., Ono, K. and Wada, Y. 2006. J. Vet. Med. Sci. 68: 9-13
4. Philbrick, W. M., Wysolmerski, J. J., Galbraith, S., Holt, E.,Orloff, J. J., Yang, K. H., Vasavada, R. C., Weir, E. C., Broadus, A.E. and Stewart, A. F. 1996. Physiol. Rev. 76: 127173.

5. Strewler, G. J. 2002. Endocrinol. Metab. Clin. North Am. 29: 629-645.

6. Thiede, M. A. 1994. J. Dairy Sci. 77: 1952-1963.

7. Tian, J., Smogorzewski, M., Kedes, L. and Massry, S. G. 1993. Am. J. Nephrol. 13: 210-213.

8. Urena, P., Kong, X. F., Abou-Samra, A. B., Juppner, H., Kronenberg, H. M., Potts, J. T. Jr. and Segre, G. V. 1993. Endocrinology 133: 617-623.

9. Wojcik, S. F., Capen, C. C. and Rosol, T. J. 1993. Exp. Cell. Res. 248: 415-422. 